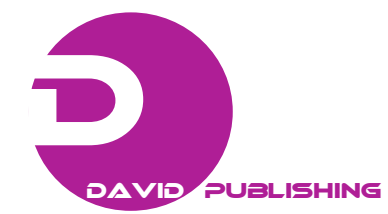

\title{
Trace Elements and Organochlorine Pesticides in Raw Milk from South Eastern Regions of Romania
}

Gabriel Dănuț Mocanu, Oana Viorela Nistor, Elisabeta Botez, Doina Georgeta Andronoiu and Viorica Maria Macovei

Department of Bioengineering in Food Industry, Food Science and Engineering Faculty, University “Dunarea de Jos”, Galati 800201, Romania

Received: August 9, 2011 / Published: March 20, 2012.

\begin{abstract}
A total of 108 raw milk samples were collected from tankers arriving at processing facilities from rural areas in eastern and northern regions of Romania from January to December 2010. Concentrations of $\mathrm{As}, \mathrm{Cu}, \mathrm{Zn}$ and $\mathrm{Pb}$ in the samples were performed using an atomic absorption spectrophotometer. Detection and measurement of the organochlorine pesticides residues $(\alpha+$ $\beta-\mathrm{HCH}, \gamma-\mathrm{HCH}$ and total DDT) were achieved by using a gas chromatograph equipped with a ${ }^{63} \mathrm{Ni}$ electron capture detector. $\mathrm{Pb}$ contents in all samples corresponded to tolerance level $\left(0.1 \mathrm{mg} \mathrm{kg}^{-1}\right)$ and in $98 \%$ of these samples were below $0.05 \mathrm{mg} \mathrm{kg}^{-1}$. All samples examined for residues of $\mathrm{Cu}, \mathrm{Zn}$ and As were completely acceptable as well. Residue levels of organochlorine pesticides in all analysed samples were far below tolerance levels, too. In $93.5 \%$ of samples $\alpha+\beta-\mathrm{HCH}$ and in $85 \%$ of samples $\gamma$-HCH was below the limit of detection $\left(0.008 \mathrm{mg} \mathrm{kg}^{-1}\right)$. In $85 \%$ of samples total DDT residues were between $<0.005$ and $0.0068 \mathrm{mg} \mathrm{kg}^{-1}$. In future studies, a greater number of milk samples from different regions of Romania should be controlled to confirm the absence of possible toxicological risks.
\end{abstract}

Key words: Cow milk, trace elements, organochlorine pesticides, atomic absorption spectroscopy, Romania.

\section{Introduction}

Milk is considered as a nearly complete food since it is a good source for protein, fat and major minerals. Also, milk and milk products are main constituents of the daily diet, especially for vulnerable groups such as infants, school age children and old age [1].

However, milk and dairy products may contain varying amounts of different toxic contaminants [2-4]. As an excretion of the mammary gland, it can carry numerous xenobiotic substances (pesticides, disinfectants, drugs, metals and various environmental contaminants), which constitute a technological risk factor for dairy products, for the related commercial image and, above all, for the health of the consumer.

Corresponding author: Gabriel Dănuț Mocanu, Ph.D., assistant professor, research fields: functional foods for disease prevention, dairy processing, processing of fruits and vegetables, physical and engineering properties of foods. E-mail: Danut.Mocanu@ugal.ro.
Today, the consumer is more demanding than in the past and expects "healthy" milk, rich in nutrients, with high biological value, but without health risks [5].

Trace elements are fairly widespread in the environment. Their level with an anthropogenic origin is much higher than the level from natural sources. These elements are non-essential for almost all living organisms. The largest amount of trace elements found in humans has been absorbed through food. Organochlorine pesticides are very toxic organic compounds of anthropogenic origin which pose a serious threat to the environment and human health.

The main organochlorine pesticides are considered to be persistent organic pollutants. These compounds are a special problem because they persist in the environment for a long time before they break down, travel over long distances to all parts of the globe and poison humans and wildlife. They tend to concentrate 
in the fatty tissues of humans and animals that are at the top in the food chain. The only way that the organisms can excrete them is through milk [6].

Many countries have adopted regulations that state the maximum residue levels of environmental pollutants in food in order to protect consumers. Current maximum residue levels for some environmental pollutants in cow's milk in Romania according with EU regulation are presented in Table 1.

\section{Material and Methods}

A total of 108 raw milk samples $(330 \mathrm{~mL})$ were collected from tankers arriving at processing facilities from rural areas from eastern and northern counties of Galati during January until December 2010. Upon collection, all the samples were placed in sterile bottles, stored at $4-6^{\circ} \mathrm{C}$ in a cool box and immediately transported to the laboratory and stored at $-20{ }^{\circ} \mathrm{C}$ until analysis.

\subsection{Analysis of Toxic and Trace Elements}

The dosage of metallic ions in milk was accomplished with the help spectrometry of atomic absorption using the Avanta PM. GBS Scientifique Equipment Victoria (Australia). For the other metals the decomposition by wet way was used according to the AOAC methods [9]. From the final solution there are determined through chemical methods, according to the national standards: copper, lead, zinc and arsenic. For the spectrometry of atomic absorption the hydrochloric solutions are preferred, because the metals halogenure are volatile in flame. Both for the verification of the reproducibility of the results, and for the better conservation of metals present in the traces, the milk samples were decomposed by wet way according to the national standard $8342 / 89$, by incineration and calcinations at $500{ }^{\circ} \mathrm{C}$, is finally dissolved in $\mathrm{HCl} 5 \mathrm{~N}$. The AAS apparatus functions with air-acetylene flame at a flame rate of $10 \mathrm{~L} \mathrm{~min}^{-1}$ air and $0.99 \mathrm{~L} \mathrm{~min}^{-1}$ acetylene in calibrating conditions for $\mathrm{R}^{2}=0.994$ [10].
Table 1 Maximum residue levels for some trace elements and organochlorine pesticides in cow's milk in Romania (all values in $\mathrm{mg} / \mathrm{kg}$ according to the Regulation EC No 1881/2006 [7] and Regulation (EU) No 600/2010 [8]).

\begin{tabular}{llll}
\hline \multicolumn{2}{l}{ Trace elements } & \multicolumn{2}{l}{ Organochlorine pesticides } \\
\hline $\mathrm{Pb}$ & 0.05 & Total DDT & 0.04 \\
$\mathrm{Cu}$ & 0.5 & $\alpha-\mathrm{HCH}$ & 0.004 \\
$\mathrm{As}$ & 0.05 & $\beta-\mathrm{HCH}$ & 0.003 \\
$\mathrm{Zn}$ & 5 & $\gamma-\mathrm{HCH}$ & 0.001 \\
\hline
\end{tabular}

Analyses of $\mathrm{Pb}, \mathrm{Cu}, \mathrm{As}, \mathrm{Zn}$ and organochlorine pesticides have been carried out at the National Sanitary Veterinary and Food Safety Authority in Galati, Romania. This paper presents the results of residue monitoring and environmental pollutant scanning of Romanian raw cow's milk from January to December 2010.

\subsection{Sample Preparation, Extraction and Cleanup}

Fat were extracted from milk according to the method of the AOAC [11]. Briefly three grams or less of the fat was dissolved into $40 \mathrm{~mL}$ petroleum ether. This was partitioned three times into acetonitrile saturated with petroleum ether $(3 \times 30 \mathrm{~mL})$. The acetonitrile fraction, after dilution with saline $(600$ $\mathrm{mL})$, was again partitioned into petroleum ether $(3 \times$ $100 \mathrm{~mL}$ ). This was dried over anhydrous sodium sulfate, and concentrated at $30{ }^{\circ} \mathrm{C}$ on a rotary vacuum evaporator to a volume less than $5 \mathrm{~mL}$ to be used for Florisil cleanup [12].

Cleanup of the extracted samples, to remove the residual fat, was performed by transferring the extract into a glass chromatographic column $(25 \mathrm{~mm}$ internal diameter) containing $25 \mathrm{~g}$ activated Florisil (60/100 mesh) topped with 1-cm layer of anhydrous sodium sulfate.

The prepared column was rinsed with $100 \mathrm{~mL}$ petroleum ether, and then the extracted sample was transferred onto the column. The column was eluted with $300 \mathrm{~mL}$ eluent $(20 \%$ dichloromethane $+80 \%$ petroleum ether). The collected eluate was concentrated to dryness on a rotary vacuum evaporator and dissolved in hexane to a volume of 5 $\mathrm{mL}$ [13]. An aliquot of each extract was transferred to $2 \mathrm{~mL}$ injection vials to be ready for the analysis with the electron capture gas chromatography. 


\subsection{Determination of Organochlorine Pesticide Residual Concentrations}

The organochlorine pesticide residues were determined by analysis of samples using a Hewlett-Packard gas chromatograph (GC-HP 5890 Series II) equipped with a ${ }^{63} \mathrm{Ni}$ electron capture detector, using a silica capillary column (HP-5 $30 \mathrm{~m} \times$ $0.32 \mathrm{~mm}$ internal diameter with $0.25 \mu \mathrm{m}$ film thickness). The carrier gas was helium at a flow rate of $2 \mathrm{~mL} \mathrm{~min}^{-1}$ through column and $30 \mathrm{~mL} \mathrm{~min}^{-1}$ make up.

The gas chromatography oven temperature was initiated at $80{ }^{\circ} \mathrm{C}$ for $2.2 \mathrm{~min}$, raised to $175^{\circ} \mathrm{C}$ (at a rate of $30{ }^{\circ} \mathrm{C} \mathrm{min}^{-1}$ ), then raised to $225^{\circ} \mathrm{C}$ (at a rate of $10{ }^{\circ} \mathrm{C} \min ^{-1}$ ) and held for $2 \mathrm{~min}$. Injection port temperature and detector temperature were maintained at $280{ }^{\circ} \mathrm{C}$ and $300{ }^{\circ} \mathrm{C}$, respectively. The sample volume injected was $1 \mu \mathrm{L}$. Calibration standard curves were created and organochlorine pesticide residues were quantitatively determined by comparison of the retention time and peak heights/areas of the sample chromatogram with those of standard solutions run under the same operating conditions. The concentrations of various residues in each sample were reported as $\mathrm{mg} \mathrm{kg}^{-1}$ on a fat basis [14].

\subsection{Statistical Analysis}

The data were analyses using Analysis of Variance (ANOVA). Comparison of means was done using Duncan's Multiple Range test at $P<0.05$.

\section{Results and Discussion}

\subsection{Milk Composition}

Milk samples of different seasons were varied in their composition. These variations are primarily due to milk changes in fat, protein, lactose and occasionally the mineral salts content of milk (Table 2).

During the summer season, more fat and protein were found in milk samples than in winter season. The differences in fat and protein contents among the season were highly significant $(P<0.05)$. The lactose content of milk samples of different season did not significantly vary.

This was expected since lactose plays an important role in maintaining the osmotic pressure of milk.

\subsection{Milk level of Toxic and Trace Elements}

The concentrations $\left(\mathrm{mg} \mathrm{kg}^{-1}\right)$ of the trace elements $(\mathrm{Cu}$ and $\mathrm{Zn})$ and the toxic metals $(\mathrm{Pb}$ and $\mathrm{As})$ in the bovine milk samples from Galati are reported in Table 3.

This study demonstrates that, in milk from Galati County the concentrations of toxic metals ( $\mathrm{As}$ and $\mathrm{Pb}$ ) were below detection limits. In the present study, As concentrations ranged from minimum values of 0.001 $\mathrm{mg} \mathrm{kg}^{-1}$ in the north and $0.005 \mathrm{mg} \mathrm{kg}^{-1}$ in the east region and there were no significant differences in arsenic levels between the regions. Significant differences in arsenic levels between traffic and industrial regions $\left(0.05\right.$ and $\left.0.04 \mathrm{mg} \mathrm{kg}^{-1}\right)$ and rural regions $\left(0.0002 \mathrm{mg} \mathrm{kg}^{-1}\right)$ were reported in Turkey [15].

$\mathrm{Pb}$ in all samples studied albeit not in dangerous concentrations, showing how this metal is ever more frequently found in milk. The presence of $\mathrm{Pb}$ in milk samples could be due to various factors: transhumance along roads and/or motorways, fodder contamination, climatic factors, such as winds, and the use of pesticide compounds $[5,16]$.

Therefore, it is necessary to monitor this metal over time to better clarify its presence in milk. The average lead content of our milk samples was between $0.001-0.005 \mathrm{mg} \mathrm{kg}^{-1}$.

Higher lead levels in milk were reported in an unpolluted area $\left(0.25 \mathrm{mg} \mathrm{L}^{-1}\right)$ and around plant and smelter areas in India $\left(0.65-0.85 \mathrm{mg} \mathrm{L}^{-1}\right)$ [17], and also in Brazil (0.23 $\left.\mathrm{mg} \mathrm{L}^{-1}\right)$ [18] and Pakistan (21.78 and $15.96 \mathrm{mg} \mathrm{L}^{-1}$ ) [19].

The levels of trace elements $(\mathrm{Cu}$ and $\mathrm{Zn})$ found were below detection limits. Copper is an essential element required in the diet due to its role in vital oxidation-reduction reactions. At supraoptimal concentrations, copper may generate toxic effects such as, dermatitis, liver cirrhosis and neurological disorders 
Table 2 Mean composition of cow`s milk samples collected from different locations of Galati County in 2010.

\begin{tabular}{|c|c|c|c|}
\hline \multirow{2}{*}{ Parameter/Component } & \multicolumn{3}{|c|}{ Locations } \\
\hline & Schela & Brăneşti & Barboşi \\
\hline Density $\left(\mathrm{g} / \mathrm{cm}^{3}\right)$ & $1.0285 \pm 0.0008^{\mathrm{a}}$ & $1.0269 \pm 0.0011$ & $1.0262 \pm 0.0004$ \\
\hline Acidity $\left({ }^{\circ} \mathrm{T}\right)$ & $18.75 \pm 0.5762$ & $18.58 \pm 0.5293$ & $18.25 \pm 0.4154$ \\
\hline Total dry substance $(\%)$ & $12.06 \pm 0.2881$ & $11.67 \pm 0.2881$ & $11.23 \pm 0.2412$ \\
\hline Fat $(\%)$ & $3.64 \pm 0.1742$ & $3.64 \pm 0.1876$ & $3.44 \pm 0.2077$ \\
\hline Protein $(\%)$ & $3.36 \pm 0.0804$ & $3.20 \pm 0.0804$ & $3.11 \pm 0.0402$ \\
\hline Lactose $(\%)$ & $4.38 \pm 0.0938$ & $4.19 \pm 0.1072$ & $4.06 \pm 0.0402$ \\
\hline Mineral salts (\%) & $0.68 \pm 0.0201$ & $0.64 \pm 0.0201$ & $0.62 \pm 0.0067$ \\
\hline Freezing point $\left({ }^{\circ} \mathrm{C}\right)$ & $-0.515 \pm 0.0181$ & $-0.493 \pm 0.0181$ & $-0.469 \pm 0.0067$ \\
\hline
\end{tabular}

${ }^{\mathrm{a}}$ : values \pm standard errors of regression.

Table 3 Trace elements and toxic metals in milk.

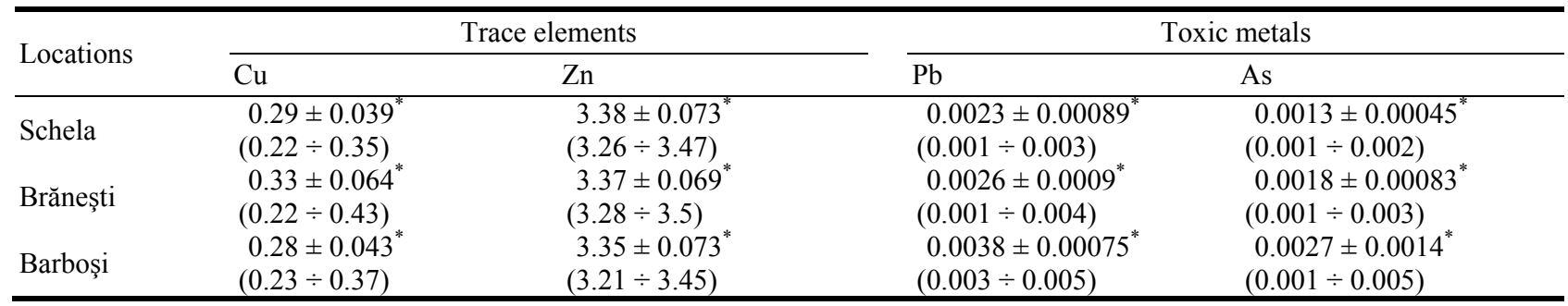

The values were expressed in mean \pm standard errors of regression and values in parenthesis indicate minimum and maximum level recorded. The mean value with similar superscripts not varied significantly at $P<0.05$.

[20]. The low concentrations of $\mathrm{Cu}$ could be due to $\mathrm{Zn}$ contained in food that interferes with the copper absorption system, explaining the presence of low levels of this metal in milk.

Zinc concentrations were measured in all raw milk samples and were between $3.26-3.5 \mathrm{mg} \mathrm{kg}^{-1}$. These values are similar to those found in other studies (21 to $41 \mu \mathrm{g} \mathrm{g}^{-1} ; 20$ to $34 \mu \mathrm{g} \mathrm{g}^{-1}$ ) [21]. The copper levels were higher than those reported in southern Poland $\left(0.2-0.3 \mathrm{mg} \mathrm{kg}^{-1}\right)$ [22], Spain $\left(60 \mu \mathrm{g} \mathrm{g}^{-1}\right.$ and $51.8 \mu \mathrm{g}$ $\left.\mathrm{L}^{-1}\right)$ [23], Calabria in Italy $\left(0.14-737.58 \mu \mathrm{g} \mathrm{kg}^{-1}\right)$ [5] and unpolluted areas of India $\left(0.101 \mathrm{mg} \mathrm{L}^{-1}\right)$ [16].

\subsection{Organochlorine Pesticide Residues in Milk}

The present study showed the presence of organochlorine pesticide residues in milk owing to their use in sanitary and agricultural purposes.

Residues of $\alpha+\beta$-HCH (Fig. 1) and $\gamma$-HCH (Fig. 2) in all 108 analyzed samples of raw cow's milk were under the limit of detection $\left(0.004 \mathrm{mg} \cdot \mathrm{kg}^{-1}\right.$ and 0.0008 $\left.\mathrm{mg} \mathrm{kg}^{-1}\right)$. In $93.5 \%$ of samples $\alpha+\beta-\mathrm{HCH}$ and in $85 \%$ of samples $\gamma-\mathrm{HCH}$ was below the limit of detection.
The present results revealed that the frequency of different isomers of $\mathrm{HCH}$ residues in dairy products on fat basis was of the order of $\gamma>\alpha+\beta$. In addition, with regard to mean concentration in the contaminated samples $\gamma$-isomer was highest $\left(0.0026 \mathrm{mg} \mathrm{kg}^{-1}\right.$ fat, location 3-Barboşi) followed by $\alpha+\beta$-isomer $(0.0004$ $\mathrm{mg} \mathrm{kg}^{-1}$ fat location 3-Barboşi).

The ratios and levels of $\mathrm{HCH}$ isomers are often used as evidence of the passed or current technical HCH application [24].

In all analyzed samples of milk, collected from Galati County, total DDT levels (Fig. 3) were below the limit of detection $\left(0.04 \mathrm{mg} \mathrm{kg}^{-1}\right)$. In $85 \%$ of samples total DDT residues were between $<0.005$ and 0.0068 $\mathrm{mg} \mathrm{kg}^{-1}$. The highest content of total DDT were 0.0068 $\mathrm{mg} \mathrm{kg}^{-1}$ for location 3 (Barboşi) and the lowest content were $0.0016 \mathrm{mg} \mathrm{kg}^{-1}$ for location 1 (Schela).

\section{Conclusions}

Residues of environmental pollutants examined in Romanian raw cow's milk were not problematic from January until December 2010; milk is safe for the 


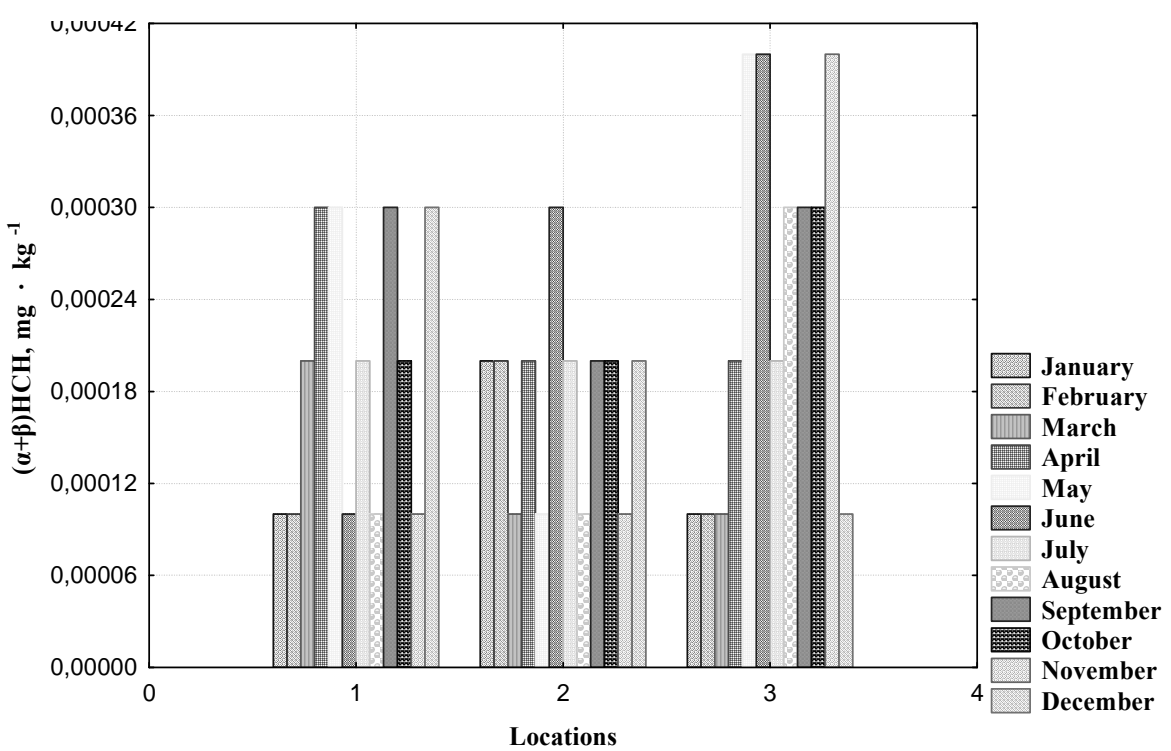

Fig. 1 Variation of the $\alpha+\beta-\mathrm{HCH}$ content.

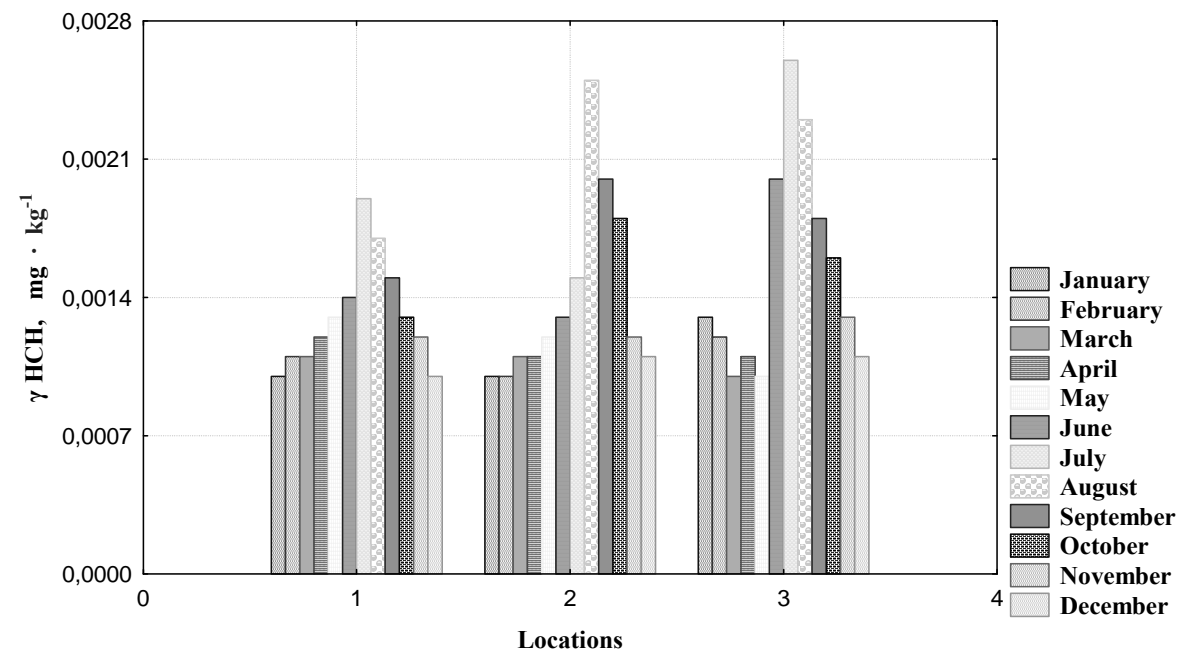

Fig. 2 Variation of the $\gamma-\mathrm{HCH}$ content.

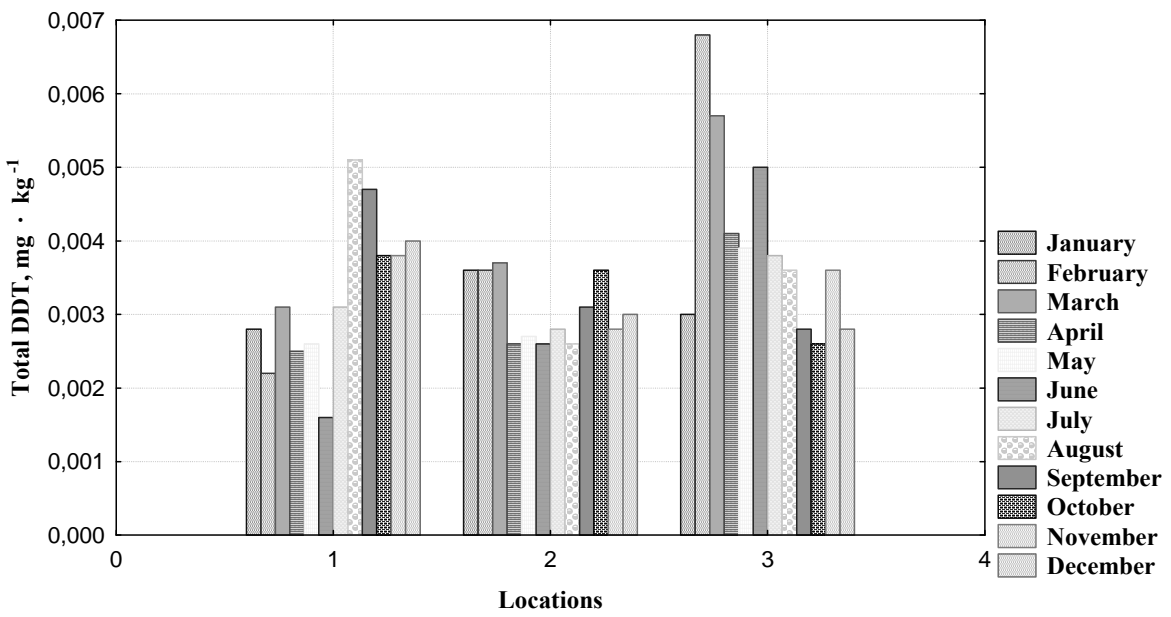

Fig. 3 Variation of the total DDT content. 
consumers. In conclusion, our data deserve particular attention not only for their significance but especially because they were recorded in Galati, a region with a high risk of environmental pollution due to the of industries. Further studies are necessary to evaluate the contents of trace elements, toxic metals and organochlorine pesticides on a greater number of milk samples from various dairy farms in Galati and to confirm the absence of possible toxicological risks in this region.

\section{References}

[1] A. Enb, M.A. Abou Donia, N.N.S. Abd-Rabou, A.A.K. Abou-Arab, M.H. El-Senaity, Chemical composition of raw milk and heavy metals behavior during processing of milk products, Global Veterinaria 3 (3) (2009) 268-275.

[2] A. Ataro, R.I. McCrindle, B.M. Botha, C.M.E. McCrindle, P.P. Ndibewu, Quantification of trace elements in raw cow's milk by inductively coupled plasma mass spectrometry (ICP-MS), Food Chemistry 111 (2008) 243-248.

[3] S. Maas, F. Gimbert, E. Lucot, N. Crini, P.M. Badot, Trace metals in raw cows' milk and assessment of transfer to Comté cheese, Food Chemistry 129 (2010) 7-12.

[4] C.I. Weber, Gh. Muresan, B. Georgescu, Organochlorine pesticide residues analysis from cow milk: A review, Bulletin UASVM Animal Science and Biotechnologies 65 (1-2) (2008) 43-48.

[5] P. Licata, D. Trombetta, M. Cristani, F. Giofrè, D. Martino, M. Calo, et al., Levels of "toxic" and "essential" metals in samples of bovine milk from various dairy farms in Calabria, Italy, Environment International 30 (2004) 1-6.

[6] V. Cerkvenik, D.Z. Doganoc, J. Jan, Evidence of some trace elements, organochlorine pesticides and PCBs in slovenian cow's milk, Food Technolo. Biotechnol. 38 (2) (2000) 155-160.

[7] Commission Regulation (EC), No 1881/2006 of 19 December 2006 on setting maximum levels for certain contaminants in foodstuffs, Official Journal of the European Union L64 (2006) 5-24.

[8] Commission Regulation (EU), No 600/2010 of 8 July 2010 on amending Annex I to Regulation (EC) No 396/2005 of the European Parliament and of the Council as regards additions and modification of the examples of related varieties or other products to which the same MRL applies, Official Journal of the European Union L174 (2010) 18-39.

[9] AOAC, Official Methods of Analysis, Maryland, 1997.

[10] T. Florea, S. Huszti Orban, G.M. Costin, Heavy Metals Contaminants in Milk and Cheese, The Annals of the
University Dunarea de Jos of Galati, Fascicle VI-Food Technology, 2006, pp. 26-32.

[11] AOAC International, Official Methods of Analysis, 16th ed., AOAC International, Gaithersburg, 1995.

[12] Z.C. Kodba, D.B. Voncina, A rapid method for the determination of organochlorine, pyrethroid pesticides and polychlorobiphenyls in fatty foods using GC with electron capture detection, Chromatographia 66 (2007) 619-624.

[13] M.A. Alawi, N. Ammari, Y. Al-Shuraiki, Organochlorine pesticide contaminations in human milk samples from women living in Amman, Jordan, Arch. Environ. Contam. Toxicol. 23 (1992) 235-239.

[14] N.M. Salem, R. Ahmad, H. Estaitieh, Organochlorine pesticide residues in dairy products in Jordan, Chemosphere 77 (2009) 673-678.

[15] O. Simsek, R. Gültekin, O. Öksüz, S. Kurultay, The effect of environmental pollution on the heavy metal content of raw milk, Nahrung Food 44 (2000) 360-371.

[16] M. Tajkarimi, M.A. Faghih, H. Poursoltani, A.S. Nejad, A.A. Motallebi, H. Mahdavi, Lead residue levels in raw milk from different regions of Iran, Food Control 19 (2008) 495-498.

[17] R.C. Patra, D. Swarup, P. Kumar, D. Nandi, R. Naresh, S.L. Ali, Milk trace elements in lactating cows environmentally exposed to higher level of lead and cadmium around different industrial units, The Science of the Total Environment 404 (2008) 36-43.

[18] V.A. Soares, M.M.M. Kus, A.L.C. Peixoto, J.S. Carrocci, R.F.S. Salazar, H.J.I. Filho, Determination of nutritional and toxic elements in pasteurized bovine milk from Vale do Paraiba region (Brazil), Food Control 21 (2010) 45-49.

[19] I. Javed, I. Jan, F. Muhammad, Z. Rahman, M.Z. Khan, B. Aslam, Heavy metal residues in the milk of cattle and goats during winter season, Bulletin Environmental Contamination and Toxicology 82 (2009) 616-620.

[20] M. Storelli, M. Barone, G. Garofalo, G.O. Marcotrigiano, Metals and organochlorine compounds in eel (Anguilla anguilla) from the Lesina lagoon, Adriatic Sea (Italy), Food Chemistry 100 (2007) 1337-1341.

[21] I. Baranowska, H. Barchanska, A. Pyrsz, Distribution of pesticides and heavy metals in trophic chain, Chemosphere 60 (2005) 1590-1599.

[22] M. Krelowska-Kulas, W. Kedzior, C. Popek, Content of some metals in goat's milk from Southern Poland, Nahrung-Food 43 (1999) 317-319.

[23] C. Sola-Larranaga, I. Navarro-Blasco, Chemometric analysis of minerals and trace elements in raw cow milk from the community of Navarra, Spain, Food Chemistry 112 (2009) 189-196.

[24] A. Jafari, C. Moeckel, K.C. Jones, Spatial biomonitoring of persistent organic pollutants in Iran: A study using locally produced butter, J. Environ. Monit. 10 (2008) 861-866. 